\title{
An Overview of Geotourism Potentials in Managing the Menace of Insecurity within Mubi Region and Environs, North Eastern Nigeria
}

\author{
Audu Vincent E. M. \\ Dept. of Civil Engineering Technology, \\ The Federal Polytechnic \\ Mubi, Nigeria
}

\author{
Bitrus Kwaji, Lawan .I. Ismaila \\ Dept. of Geological Technology, \\ The Federal Polytechnic \\ Mubi, Nigeria
}

\author{
Jibrin Umar \\ Dept. of Civil Engineering Technology, \\ The Federal Polytechnic \\ Damaturu, Nigeria
}

\begin{abstract}
This research paper focused on the overview of geotourism potentials in managing the menace of insecurity within Mubi region and environs, North Eastern Nigeria. Data collection was carried out by using the primary \& secondary data collection methods. The primary data collection involved geological mapping, photograph taken of geosites using Itel phone camera (360 HD cam) and the secondary data collection was gathering literature materials on the research topic. The research revealed that, geological features such as Cameroon mountain, Mandra mountains, Mubi south quarrying sites are used to manage the menace of insecurity, they serve as escape routes, barriers for protection, provide income, site for traditional briefs, provide minerals like uranium for the manufacturing of atomic bombs to combat insecurity e.t.c. It also shows that geotourism is geologically based, sustainable, geologically informative, locally beneficial and presents tourist satisfaction.
\end{abstract}

Keywords: Geotourism Potentials, Insecurity, Managing, Menace, Mubi Region.

\section{INTRODUCTION}

Geotourism is a relatively established and sustainable form of tourism.It is a new type of tourism and has been developing rapidly as a global phenomenon in the last two decades, (Dowling, 2008). Reflecting the explosive growth in global geotourism, there has been a large number of conferences on the topic held in some years past. They include the Inaugural Global Geotourism Conference held in Perth, Australia in August 2008; the World Heritage and Geotourism Conference hosted by the Geological Society of South Africa, held in Pretoria from 4-5th June, 2009; Geotour 2009 held in the High Tatra Mountains, Slovakia from 6-10th September, 2009; and now, the 8th European Geoparks Conference held at Geopark Naturtejo and the Second Global Geotourism Conference was held at the island of Borneo, at Gunung Mulu World Heritage Region, Sarawak, Malaysia from 17-20th April, 2010. Another development has been the establishment of the International Association for Geotourism (IAG), set up in Eastern Europe (www.iageotour.com). They recently announced plans to host what they have billed as the First World Congress of Geotourism next year. In addition there has been a number of

books on the topic Geotourism, (Dowling \& Newsome, 2006) and Geotourism in Ethiopia, (Dong et al, 2010). Two global books emerged from the 2008 Inaugural Global Geotourism Conference in 2010. They are;

- Global Geotourism Perspectives and Geology and Geotourism:

- The Tourism of Geology and Landscape (both Dowling \& Newsome, In Press, due April 2010, (Hose 2005).

The main aim of geotourism is to bring tourists to geological heritage (geoheritage), orient, educate them and to gain experience in the earth's geological features and resources, (Bujdoso et al, 2015). The focus of geotourism is that the potentials which are the earth's geological features will foster environmental and cultural understanding, prevention, conservation and usual beneficial to the inhabitants of the area, (Dowling \& Newsome, 2006).

Geotourism as a new branch of geological science and tourism has been defined often recently and its definitions have been changing and improving, (Dong, et al, 2010). According to the most definitions, geotourism is a form of tourism related to geological and geomorphological sites and features such as landscapes, rocks, landforms, outcrops, minerals, fossils, sediments e.t.c,. Geology is the study of the earth's features/process of its formation and geomorphology is the study of the landforms. So the features mentioned are geological potentials and it is focused on the geological heritage of an area and oriented on sustainability, conservation, and community benefits. As a branch of sustainable tourism, it helps in the managing of menace caused by insecurity within Mubi region and at least within the geographical locations of the geosites. Despite geotourism, is a recently recoganised and established form of tourism, it becomes a global phenomenon, (Newsome, 2011). Nevertheless, research in the field of geotourism have brought many authors to the 
definition of various geotourism forms, including underground geotourism, (Gray et at.,2013), rural geotourism, urban geotourism, (Dowling, 2011,) health and wellness geotourism, (Brocx, 2013 or road side , (Gray et al, 2016).

According to Cambridge advanced learners dictionary, managing refers to bring about or succeed in accomplishing solution to a problem, sometimes despite difficultly or hardship. Therefore, to manage insecurity within the Mubi region, geotourism potentials like landforms, rocks, mining sites, mountains, e.t.c., are very vital as a tool. Also, menace is defined by Oxford English dictionary, as a thing or a person that is likely to cause a threat or danger or likely to cause harm. The problems or the threats of the insecurity within the Mubi region can be managed and minimized by the use of geotourism potentials which made up geoheritage, geosites and geomorpholosites.

\section{BACKGROUND \\ 1. Concept of Geotourism}

Geotourism is basically 'geological tourism'. The main concentration of the geological element is geology and landscape and comprises both 'form', such as 'landforms, landscapes, rock outcrops, rock types, sediments, soils, minerals and crystals, and 'process', such as volcanism, erosion, glaciation e.t.c, (Dowling, 2011). Hose, (2005) suggested that geotourism has "some overlap with ecotourism, sustainable tourism and alternative tourism and potentially much overlap with educational travel and environmental nature based and heritage tourism". Therefore, although geotourism has a connection with ecotourism, cultural tourism and adventure tourism, it is a distinctive form of tourism that is not synonymous with any other tourism forms, (Dowling, 2011). Appreciation of the geological and/or geomorphological heritage, termed geoheritage, of landscapes and their relationship to wider ecological and cultural heritage issues, is viewed by Dowling (2011) as a low-risk method of enhancing tourist income and nature conservation, particularly in developing countries. Tourist activities which focus on geology and landscape geomorphology are termed geotourism. The use of the prefix 'geo' has proliferated in recent years as a result of increasing appreciation of the relationships between geology and landscape, and due to an increase in demand for sustainable, ethical geotourism (Brocx and Semeniuk, 2007). In addition to geoheritage and geotourism, the following terms are also commonly used (definitions adapted after Gray 2013):

* Geodiversity is the the range or richness of geological and/or geomorphological features types and/or their attributes found within a given region. Geodiversity is the geologic equivalent of biodiversity.

* Georesources is the valuing from different perspectives of particular geological and/or geomorphological features or their attributes.

* Geoconservation is the the conservation of geological and/or geomorphological features or their attributes.
* G Geoparks is the area where the geoheritage and all heritage components (archeological, ecological, historical, intangible \& cultural elements are used as a tool.

* Geotope is the specific geologic and/or geomorphologic associations that are found within a specific spatial area. A geotope is the geologic equivalent of an ecotope.

In fact, geotourism research has being going on for the past two decades, this present will like to give an overview of geological potentials which can be used to manage the menace of insecurity within Mubi region and environs, north eastern Nigeria.

\section{Principles of Geotourism}

Geotourism may be further described as having a number of essential characteristics. These elements combine to shape geotourism in its present form. It comprises a number of interrelated components all of which should be present, for authentic geotourism to occur. There are five key principles which are fundamental to geotourism. They are that geotourism is geologically-based (that is, based on the earth's geoheritage), sustainable (ie: economically viable, community enhancing and fosters geoconservation), educative (achieved through geo-interpretation), locally beneficial, and generates tourist satisfaction. The first three characteristics are considered to be essential for a product to be considered 'geotourism' while the last two characteristics are viewed as being desirable for all forms of tourism, (Hose, 2005).

\section{Geotourism Challenges}

- The name 'geotourism is globally understood to geological, but the US geographic continues to use the word to the meaning 'geographic'.

-Discerning geotourists i.e geologists have already learned about the geotourism destination before visiting.

-Delivering quality products.

-Sustainability i.e another key issue is that of environmental (ecological, cultural and economic), so geotourism need to be essential, protected and conserved.

\section{MATERIALS AND METHODOLOGY}

A. Materials

\section{Study Sites}

The study sites for this research work is Mubi region and environs, which is located between latitudes $10^{\circ} 30^{\prime} \mathrm{N}$ and $10^{\circ} 05^{\prime} \mathrm{N}$ of the equator and between longitudes $13^{\circ}$ $10^{\prime} \mathrm{E}$ and $13^{\circ} 30^{\prime} \mathrm{E}$ of the Greenwich Merdian GSN, (2013).

\section{B. Methodology}

The data collection for this research was done in two (2) ways. The Primary and secondary data collection. The Primary data collection involved the geological field mapping for observation of geotourism potentials, photographic images of some sites, which were captured 
using Itel phone (Itel 1556) digital camera to visualized geological features, landforms, landscapes, rock types, outcrops, sediments, minerals e.t.c., while the secondary data collection was the gathering of literature materials on the research project.

\section{RESULT AND DISCUSSION}

A. Result

The result of this research work are presented below in Plates 1 and 2 as some of the geotourism potentials investigated.

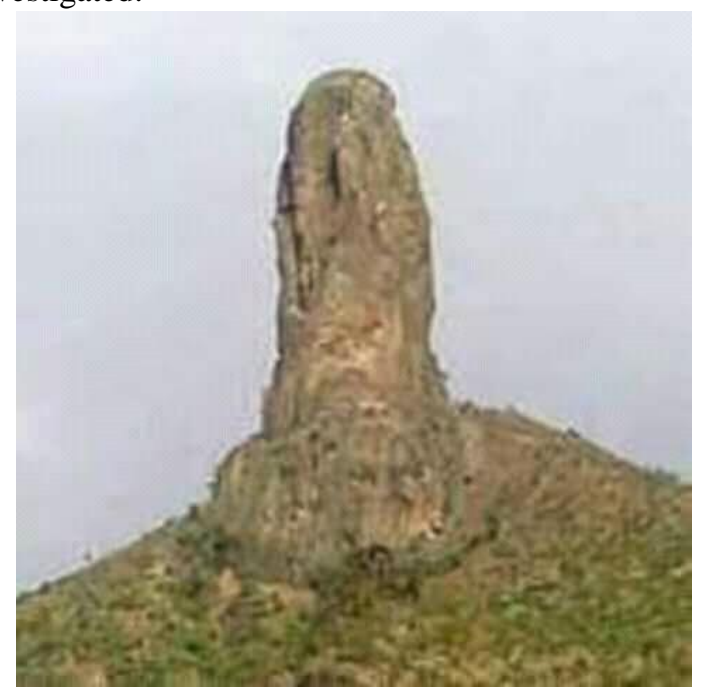

Plate 1: Cameroun mountain showing an example of geosites. Source; Researchers field data

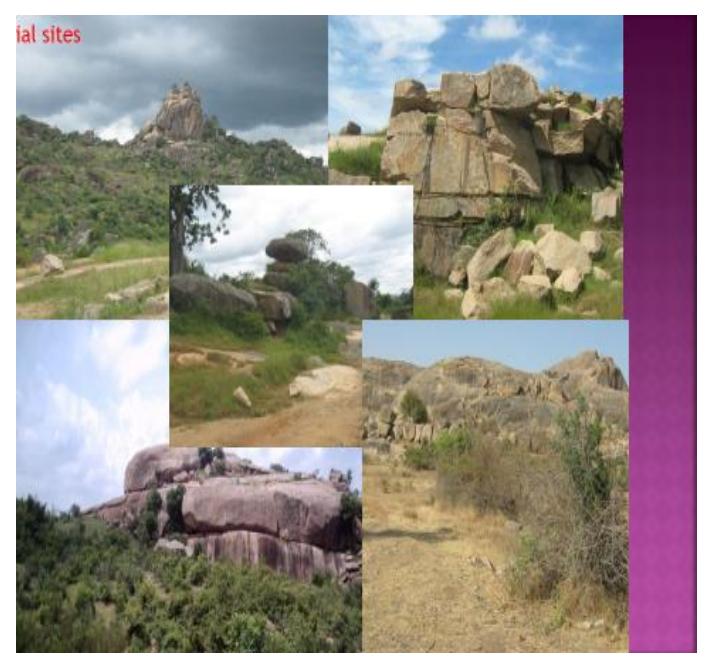

Plate 2: Rocks which are used for quarrying (quarry geosites). Source; Researchers field data

\section{B. Discussion}

From the diagram above (plate 1 and plate 2), it indicates geological features composed of landscapes, landforms, rock types, outcrop which will help in managing the threat of insecurity through using them as escape routes, traditional brief sites, quarrying for providing income to combat insecurity e.t.c.

\section{CONCLUSION}

I predict that the face of the future of tourism generally will be shaped by alternative forms of tourism especially geotourism.

\section{EFERENCES:}

[1] Brocx M, Semeniuk V.Brocx M, Semeniuk V (2007); Geoheritage and eoconservation - History, definition, scope and scale. J R Soc Western Australia 90:53-87.

[2] Bujdosó, Z., Dávid, L., András, Z., Tenk, W. (2015); Utilization of Geoheritage in Tourism Development, Procedia - Social and Behavioral Sciences.188, 316-324

[3] Dowling, R., Newsome, D.(2010);Geotourism: Global Geotourism Perspectives. Oxford: Goodfellow Publishers,262 pp. ISBN 978-1906884-17-8.

[4] Dong, H. M., Song, Y. G., Chen, T., Zhao, J. B., YU, L. P.(2013); Geoconservation and geotourism in Luochuan loess national geopark, China. Quaternary International. 334-335, 40-51.

[5] Dowling, R., Newsome, D.(2006); Geotourism. Oxford: Elsevier, ISBN 0-7506-6215-8.260 pp.

[6] Dowling R. K (2011); Geotourism's global growth. Geoheritage 3:1-13

[7] Gray M., Gordon JE, Brown EJ (2013) Geodiversity and the ecosystem approach: the contribution of geoscience in delivering integrated environmental management. Proc Geol Assoc 124:659673

[8] GNS, (2013); Geological Survey of Nigeria, sheet 1, pp 1-60

[9] Hose, T. A.,(2012);3G's for Modern Geotourism; Geoheritage.4(12), 7-2

[10] Http:www.advancedlearnersdictionary.managing/menace.com 